\title{
Benevolence Attitudes of Social Assistance and Solidarity Foundations' Personnel According to Their Administrative Profiles: A Qualitative Research in the Case of Sakarya Turkey
}

\author{
Dilek Peri (Corresponding Author) \\ Postgraduate at Sakarya University \\ Institute of Social Sciences, Labour Economics and Social Policy \\ Esentepe Campus 54050 Serdivan / Sakarya / Turkey \\ E-mail: dilekperi82@hotmail.com
}

Received: April 9, 2020 Accepted: May 7, 2020 Online published: May 12, 2020

doi:10.5296/ijhrs.v10i2.17016ＵRL: https://doi.org/10.5296/ijhrs.v10i2.17016

\begin{abstract}
Social assistance, as in the world today is an important mechanism in the fight against poverty in Turkey. Social assistance and solidarity foundations in Turkey are active institutions that provide the functionality of this mechanism. Although these foundations are important in terms of social policy; it is possible to evaluate the profiles, career problems, communication skills and benevolence attitudes of the personnel of the foundation with the human resources discipline. This research has been created based on the question of what kind of relationship is between the profiles and benevolence attitudes of foundation personnel. Turkey Sakarya in all a foundation within the sixteen districts of the province in total personnel made a qualitative research data analysis provided by in-depth interviews and findings have been obtained by combining the coding method similar answers. The study was shaped in the field research process of a thesis that was not published with the qualitative research method in the context of social policy when a foundation staff emphasized the need to look at the subject from their viewpoint. Interview questions were reconsidered and this study was directed with the idea that sufficient information was provided, and analyses and evaluations were made.
\end{abstract}

Keywords: social assistance, social assistance and solidarity foundations, benevolence, administrative profile, personnel attitudes, Turkey 


\section{Introduction}

Today, the concept of social assistance in the world and in Turkey refers to a widely cited case on the subject. In the context of welfare states, there are various operability and coordination problems of this concept, even if they are examined at different levels of development.

Within different welfare regimes for different countries, it will be possible to mention advanced social assistance systems based on citizenship (Gough, 2001: 165,166). In fact, social assistance is the rudimentary form of the concept of social security, it is the last institution to apply for (Demirbilek, 2005: 37).

In this study conducted in Turkey, social assistance and solidarity foundations, which were studied from social assistance provider organizations. Although social assistance and its foundations are the subjects of social policy science, the study deals with a number of concepts related to the careers of foundation personnel. Among these concepts; foundation personnel's profiles, attitudes, career improvements can be sorted.

In the research, it is aimed to determine the relationship between these concepts used. Evaluation of the attitudes of the personnel of the foundation according to their profiles, especially their benevolence, is among the findings expected in this research. Also, career improvement opportunities and perceptions of the success of the foundation personnel are included.

This research was obtained as a result of the re-evaluation of some of the questions used in the in-depth interview process of a thesis that has not been published in the social policy discipline in the human resources discipline. While the unpublished thesis is perception research on the role of social assistance in fighting poverty, this limited study is concerned only with the career characteristics of foundation personnel. Sampling for Turkey Sakarya social assistance and solidarity foundations located in each district of the province were selected. In each foundation, an in-depth interview was made with a staff of the institution and the research process was carried out by coding meaningful answers.

Because, in the studies carried out on a sample for a specific purpose, the size of the sample is shaped in the light of the information available. As long as the information increases, the sample can be expanded and the sample can be limited at the point where no new information can be obtained (Merriam as cited in Turan, 2013: 79). Therefore, an interview with staff at each foundation on a district basis was considered sufficient. Because, in the districts that have different socioeconomic elements and where the local people have different economic characteristics, the execution of the works can be different for each foundation, but the staff within the same foundation state similar answers.

This study is spontaneous research in the thesis field research process. In one of the districts visited for the interview, this study was created in response to the request of foundation personnel to conduct research on them. Interview questions were re-examined and after analysing that some of the questions could be findings in this research, in other words, it was understood that significant findings could be made, and the analysis of this research was 
emphasized.

\section{Social Assistance and Solidarity Foundations in the World and Turkey}

Social security, social assistance, social service have become an issue that needs to be carried out in a coordinated and functional way in Western countries and less developed countries after 1980. While ensuring this, it is necessary to overcome the authority and coordination problems (Demirbilek, 2005: 40). Therefore, the importance given to these concepts has increased throughout the world in this period.

In Turkey based on the dynamics of modernization parallel to the proclamation of the Republic social assistance to the poor has been an area where local administrations and Islamic institutions operate predominantly. State institutionalization of assistance was realized for the first time in 1976 for elderly and disabled citizens (Buğra\& Keyder, 2006: 239). The institutionalization of social assistance and solidarity foundations and the raising of administrative demands coincide with the same period in Turkey.

\subsection{Notion and Contents}

There have been differences in the concept of social assistance over time, because of the occurrence of other concepts equivalent to social assistance (Taşçı, 2008: 129). Despite all its definitions, social assistance is a mechanism that focuses on the needy population. The exact equivalent of this definition differs in Europe and America (Bahle et al., 2010: 448). Social assistance is a support system provided by the government to indigent citizens in Turkey. Likewise, the definition and limits of neediness are determined by law.

People's becoming in need may be based on economic risk. In addition to illness and disability, natural disasters are among these reasons. Death of the head of the family or unemployment is among the reasons for neediness. While the income is gone off, the needs continue (Aktan\& Vural, 2002: 2). The neediness criteria can also be relative, such as the reasons for neediness, depending on the type of social assistance provided.

\subsection{Functions}

Today, the function of the social assistance method is not denied in alleviating poverty, which is a social problem (Demirbilek, 2005: 39). In addition to preventing poverty, it is not possible to define social benefits functionally. Because it functions to prevent poverty at a minimum level beyond a certain target group. Among the beneficiaries, it is possible to frequently see the elderly, disabled, single parents and long-term unemployed (Bahle et al., 2010: 461). Social assistance, which can be long-term and continuous in special situations, is often given to eliminate a temporary risk.

The main purpose of social assistance is to provide income insurance to people in need until their situation disappears. Because the basis of social assistance is the principle of protecting people with decent living and thinking that human is the most valuable living creature. Social assistances were implemented to make the people feel safe as a social subject. With this assurance approach, it is aimed not only to protect people, but also to be able to reach a level that will sustain their lives on their own (ASAGEM 2010: 29). 


\subsection{Missions}

Social assistance does not have a specific target audience, but the profiles of the beneficiaries are similar. Those in the low-wage group benefit from these assistances on vehicles that are increasingly tested (Bahle et al., 2010: 448,449). Although the types of social assistance and benefits conditions vary from country to country, the tests and assistances provided show similar characteristics. Social assistance is a signal of the welfare state, but they differ in the context of welfare regimes.

Welfare states, which are considered within the welfare regimes, show different characteristics. On the regards of welfare regimes (Esping-Andersen, 1990: 55):

It can provide service and income security, but it has a social stratification system.

Class features are decisive for societies.

Organizationally, social solidarity, class division, statuses figure an effective role.

In the context of welfare regimes, it is possible to examine the types of social assistance in different categories. It will be possible to mention eight main categories (Gough, 2001: 165,166):

1. Selective welfare systems; Australia, New Zealand.

2. The singular example of the United States.

3. Welfare states with integrated security networks; Ireland, England, Canada.

4. Dual social assistance systems; France, Belgium, Germany.

5. Citizenship based systems; Scandinavian countries outside the Netherlands and Norway.

6. Rudimentary social assistance systems; Southern Europe, including Turkey's welfare regime inside.

7. Decentralized, optional; Norway, Austria, Switzerland.

8. The singular, centralized discretionary relief system in Japan.

In the doctrine, social assistance is stated as limited content in other words monetary (cash) assistance. However, when taken from another point of view, social assistance does not include only cash benefits, but also public relief is included in the definition of social assistance (Demirbilek, 2005: 37).

Social assistance in Turkey, evaluated in the Southern European welfare regime category and its types are public relief, cash, conditional and unconditional, protection and indemnity are qualified.

The definition of general assistance is as follows: If the people in need are given public relief, in other words, this is called a goods social assistance. The difference here occurs at the point of providing the goods or services needed by the needy person directly (Saran, 1997: 438). Such social assistance is the oldest known type of assistance (Kesgin, 2014: 48). Reducing 
public relief in Turkey will increase the efficiency of social assistance by increasing the cash assistance applications (Şener, 2010: 21), that opinions are also available.

While being unconditional is the general system of social assistance; certain conditions may be imposed on education, employment, health assistance. The pieces of training that are required to be taken are perceived as the worth of the assistance provided in this regard. Especially in health, regular checks are one of the most important conditions (Kesgin, 2014: $51)$.

In Turkey, conditional cash transfer (CCT), was first put into practice in 2004. The aim is to reduce the effects of the 2001 crisis after the 1999 Earthquake with the support of the World Bank and to turn social assistance into an institutionalized structure. Conditional cash transfer, which is implemented within the framework of social assistance and solidarity foundations, attaches importance to fighting poverty (Dodurka, 2014: 3).

For the definition of protection and compensation qualified social assistance, state workers benefit from such social assistance in case of any damage when they are harmed. The most well-known is the social assistance provided by the state in order to support the losses during military service (Kesgin, 2014: 51).

\subsection{Personnel Profiles of Social Assistance and Solidarity Foundation in Turkey}

The staff working in social assistance and solidarity foundations in Turkey can be analysed in two categories (Kutlu, 2015: 197,198):

For the social assistance worker; In addition to graduating from a faculty at the undergraduate level, having high communication skills and getting enough points in the central government exams, special conditions can also be sought. Programs such as economic and administrative sciences, political sciences, sociology, and psychology can be emphasized. The officers are recruited at the discretion of the board of trustees.

The bureau officer is also selected and appointed by the board of trustees.

Foundation personnel works on contractual status, not permanent staff.

\section{Analysis of the Administrative Profiles of Foundation Personnel}

This research, which is based on social assistance and solidarity foundations and their personnel, has taken place spontaneously in the process. Turkey, Sakarya province, the base area of study; from the interview process of a wider perspective thesis, questions or questions have been created since a social assistance and solidarity foundation staff stated that research on their working conditions would be original. This qualitative research, which is not part of the direct thesis, was obtained by reassessing and analysing the interview findings used for the thesis from a different perspective.

Human and social life has basic dynamics. It is not always possible to explain them with numerical data and relationships as in natural sciences. Only qualitative research methods can answer the importance given to questions such as "why" in social sciences (Gürbüz\& Şahin, 2017: 405). The qualitative research process was preferred because of these characteristics of 
social sciences and the questions asked to be answered were based on wanting to find more reasons.

Research is a qualitative research process in which observations are also effective. The research was directed in line with the impressions gained in the process, the observations made and the demands of the personnel in the social assistance and solidarity foundations to conduct research.

Another way of collecting data is to observe, informal interviews and other conversations can be evaluated in this. Fieldwork includes all these activities. If you can make objective evaluations in a systematic and specific question in your observations, you will be able to achieve reliable results. There should be a theoretical framework and a problem focus on what to look for when observing (Merriam as cited in Turan, 2013:113-115):

The physical environment should be examined.

The characteristics of the participants should be determined.

Activities and interactions in the environment should be detailed.

Conversations with others should be evaluated.

Details, physical clues, gestures and facial expressions should be followed.

The realism of behaviours should be discussed with the observer effect.

\subsection{Demographic and Socioeconomic Features of Foundation Personnel}

Turkey's social assistance and solidarity foundations within the educational qualifications of the personnel employed, communication skills and work areas are treated selectively in terms of competence, but authorities in this recruitment process (board of trustees) are realized by. In addition to the provision of certain training, some of the interviewed personnel mentioned the serious lack of career improvement during the study period. Personnel mentioned not only the lack of training provided to improve a career, but also the difficulties in working life.

In addition to the difficulties encountered in working life, the competencies of the interviewed personnel should also be evaluated. Especially communication and empathy abilities gain importance and their addressing to the people they are dealing with is important. Benevolence attitudes are the focus of the study. Also, the structure of supportive and sharing attitudes towards a researcher during the study will be discussed. In this sense, it will be possible to list the questions of the research as follows:

What are the benevolence attitudes of foundation employees?

How are these attitudes related to the following factors?

Age, gender, educational background, professional experience and other.

What are the viewpoint of foundation personnel towards success?

What are the working conditions of foundation personnel? What are the difficulties 
encountered?

What should be done to improve working conditions?

The research was carried out in the form of an in-depth interview with a staff from each foundation in the social assistance and solidarity foundations in sixteen districts of Sakarya, Turkey. During the interviews conducted as a participant-observer, both the interview and the opportunity to observe during the working hours of the foundation were provided. Thus, in addition to the statements of the working interviewers, observations were also given importance.

The profiles of sixteen interviewers from foundation personnel are examined below:

\subsubsection{Age}

Internal and external factors are effective in the career management of personnel working in an institution (Uğur, 2016: 167). In addition to internal factors, the demographic characteristics of the staff can provide success and satisfaction in working life; stress can also create dissatisfaction.

In addition to other demographic and socioeconomic features (gender, civil status, educational background, professional experience, job satisfaction), age is also an effective element in terms of career improvement and stress. Although there are different relationships between age and stress (Özmutaf, 2006:77), there is a relationship between age and recruiting, improving the experience gained at work.

Table 1. Age Profiles of Social Assistance and Solidarity Foundations Personnel

\begin{tabular}{|l|l|l|}
\hline AGE & f & $\%$ \\
\hline $20-29$ & 1 & 6,25 \\
\hline $30-39$ & 9 & 56,25 \\
\hline $40-49$ & 6 & 37,5 \\
\hline
\end{tabular}

Foundation personnel is hired from various age groups, but their job starting age is between 20 and 25 considering the time spent in the profession. Although foundation personnel is working in contract status, it is observed that they are engaged for a long time considering time spent in the profession and their age.

\subsubsection{Gender}

Turkey is categorized in the southern European welfare regimes, when examined in terms of employment based on gender relations on a sectoral basis, the number of women compared to men working in the service sector is still low (Selek Öz ve Peri, 2019: 12). Although Turkey to the EU adaptation process, patriarchal social structure hinders women's employment conditions of working life (Güler Müftüoğlu, 2006: 43). Even so women's employment in the service sector in Turkey is following a increasing trend in recent years (Tokol ve Alper, 2018: 339,341). The high rate of employment of women with high education levels also contributes to this (Selek Öz ve Peri, 2019: 16). However, women continue to work across the globe as well as in some industries and occupations predominantly in Turkey (Tokol ve Alper, 2018: 
$335,336)$.

Women in social assistance and solidarity foundations in Turkey take place in the service sector so women are employed in very numerous foundations. It has been observed that the number of women and men working in this field is almost equal, and even, in some foundations, the number of women is high. It was noteworthy that the education levels of the female personnel employed in the foundations interviewed were generally high.

Table 2. Gender Profiles of Social Assistance and Solidarity Foundations Personnel

\begin{tabular}{|l|l|l|}
\hline GENDER & f & $\%$ \\
\hline FEMALE & 9 & 56,25 \\
\hline MALE & 7 & 43,75 \\
\hline
\end{tabular}

In the sector where women work predominantly, female personnel may experience some security problems during the social investigation. In fact, the same situation occurs in a different way among male officials, only in homes where women are present, problems may arise during the investigations. Because in some foundations, female personnel is more, while in others it is the opposite. In this respect, it would be beneficial to distribute female and male personnel in foundations for each foundation in a balanced way.

During the research process, some criticisms were directed to women staff in foundations. In the context of gender-based roles, it was emphasized that female employees are more exposed to emotional exploitation by citizens who application help.

\subsubsection{Education Status}

It would be correct to define education as "The process of formalizing attitudes and behaviours through information" (Uğur, 2016: 105).

Education investments are called human capital and are acquired through formal education and on the job experience in a limited way. In the broad meaning; it encompasses various activities, much of its value comes from formal and informal education programs (Thurow, 1969: 67-70).

Sometimes theoretical difficulties may arise between the institution worked and the academic education received, and this is tried to be eliminated with the training taken in the workplace throughout the working life. Nevertheless, education supported by the government prepares the ground for working in the workplace. Before the workplace starts, he/she may request that the knowledge gained about the job be completed or be open to improvement. Theoretical or academic education also has a relationship with promotion and communication skills (Sabuncuoğlu, 2013: 125, 126). Education should be continuous in an institution in terms of human resources. The reason for this is not only to train newcomers who come to work with theoretical knowledge, but also to provide internal promotion of existing personnel (Uğur, 2016: 171). 
Table 3. Education Status Profiles of Social Assistance and Solidarity Foundations Personnel

\begin{tabular}{|l|l|l|}
\hline EDUCATION STATUS & $\mathrm{f}$ & $\%$ \\
\hline SECONDARY EDUCATION & 2 & 12,5 \\
\hline ASSOCIATE DEGREE & 2 & 12,5 \\
\hline BACHELORS DEGREE & 3 & 18,75 \\
\hline POSTGRADUATE & 2 & 12,5 \\
\hline MASTER'S DEGREE & 7 & 43,75 \\
\hline
\end{tabular}

Foundation personnel emphasized the necessity of providing vocational training by the centre of the institution rather than the academic training they receive. They emphasized that they improved the work through experience during their working life.

Here, it is believed that it will be beneficial to apply a method (Uğur, 2016: 118,119) that allows them to analyse their real personality emotionally by discussing on a pre-determined topic with appropriate groups of 10-15 people under the name of sensitivity education.

In addition, the necessity of a specialist psychologist or sociologist to work in foundations has been emphasized by many interviewees.

\subsubsection{Professional Experience}

For professional experience, it is possible to define a business with the concept of "learning to do it right by removing it from mistakes in the process" (Uğur, 2016:45).

When education and professional experience come together, it provides many more benefits than just education. This is seen more clearly in on the job training. Most jobs require specific on-the-job vocational training that is not acquired at school (Thurow, 1969: 71).

Table 4. Professional Experience Profiles of Social Assistance and Solidarity Foundations Personnel

\begin{tabular}{|l|l|l|}
\hline $\begin{array}{l}\text { PROFESSIONAL } \\
\text { EXPERIENCE }\end{array}$ & $\mathrm{f}$ & $\%$ \\
\hline $1-5$ & 0 & - \\
\hline $6-10$ & 5 & 31,25 \\
\hline $11-15$ & 7 & 43,75 \\
\hline $16-20$ & 3 & 18,75 \\
\hline $21-$ & 1 & 6,25 \\
\hline
\end{tabular}

Foundation personnel stated that as the time in the profession rises, they focus on the job more easily. In addition, they stated that the problem of carrying home thoughts about work decreased inversely proportional to the time spent in the profession.

Many foundation officers interviewed stated that they wanted to carry out various activities in the name of career improvement, but could not find an opportunity due to their work intensity. This will be examined among the career improvement problems of foundation personnel. 


\section{Macrothink}

\subsection{Analysis of Interview Questions}

According to (Merriam as cited in Turan, 2013: 163, 164), the following suggestions were taken into account during the analysis of the interview questions: limiting the study, ensuring that the analysis is directed towards the study type, ensuring that the questions are analytical, benefiting from the previous observations, getting self-audience view over time, turning the learned into short notes, to make experiments related to working on the participants, to scan the literature while on the field, to make projections about the concepts, to use visual methods.

In the process, this method(s) was followed to limit the research data and to obtain meaningful findings.

\subsubsection{Interpreting Professional Competence and Success}

Those who realize the concepts of "value" and "difference" in the institution they work with will again be those working in that institution. For this reason, revealing the talents of the employees is one of the requirements of corporate success. Defining and improving the talents of the employees should be taken as a basis (Doğan\& Demiral, 2008: 162).

Table 5. Success Interpretation Rates of Social Assistance and Solidarity Foundation Personnel

\begin{tabular}{|l|l|l|}
\hline $\begin{array}{l}\text { Personnel's viewpoints on } \\
\text { finding } \\
\text { successful }\end{array}$ & hemselves & $\%$ \\
\hline Adequate and successful & 8 & 50 \\
\hline $\begin{array}{l}\text { Should be supported and } \\
\text { improved }\end{array}$ & 8 & 50 \\
\hline
\end{tabular}

Foundation staff's interpretation of their own success is also given in the table above. The number of personnel who find themselves sufficiently competent and successful and who have aspects to be improved is equal in the sample.

The table below shows the emphasis of foundation personnel on success:

Table 6. Success Comments of Personnel of Social Assistance and Solidarity Foundations

\begin{tabular}{|l|l|}
\hline $\begin{array}{l}\text { Adequate and } \\
\text { successful }\end{array}$ & \\
\hline I:1 & $\begin{array}{l}\text { Social assistance has an important place in the fight against poverty, in this } \\
\text { respect, I consider ourselves successful. 11.04.2019 }\end{array}$ \\
\hline I:2 & $\begin{array}{l}\text { The assistance provided by social assistance and solidarity foundations is } \\
\text { sufficient because we have a wide range, so we are a successful institution. } \\
\mathbf{1 2 . 0 5 . 2 0 1 9}\end{array}$ \\
\hline I:3 & $\begin{array}{l}\text { We can afford it because we work in a small district, yes we are successful. } \\
\mathbf{1 0 . 1 2 . 2 0 1 9}\end{array}$ \\
\hline
\end{tabular}




\begin{tabular}{|c|c|}
\hline $\mathrm{I}: 4$ & I consider ourselves successful, we can deal with problems. 10.12.2019 \\
\hline $\mathrm{I}: 6$ & $\begin{array}{l}\text { In order to be able to provide accurate information, I visit the households with } \\
\text { the officers as much as possible, this allows us to be effective. It is a successful } \\
\text { aspect of my duty to improve empathy, and I am happy that I have a job that I } \\
\text { like doing so. 16.12.2019 }\end{array}$ \\
\hline I:7 & $\begin{array}{l}\text { In terms of the quality of work we work, it satisfies spiritually very much. I } \\
\text { believe that the people working in this institution are selected people. We get } \\
\text { benefaction and prayer. It is a suitable place for people to feel good. This is } \\
\text { reflected in our success.19.12.2019 }\end{array}$ \\
\hline $\mathrm{I}: 10$ & $\begin{array}{l}\text { I interpret ourselves successfully, there are not many people in need in our } \\
\text { district, and this is a district where people are engaged in agriculture. } \\
\text { 13.01.2020 }\end{array}$ \\
\hline $\mathrm{I}: 15$ & $\begin{array}{l}\text { We are successful. Because of we active in the whole district and we can afford } \\
\text { it.11.02.2020 }\end{array}$ \\
\hline $\begin{array}{l}\text { Should be } \\
\text { supported and } \\
\text { improved }\end{array}$ & \\
\hline $\mathrm{I}: 5$ & $\begin{array}{l}\text { We are also in contact with local officials because the district is small, we have a } \\
\text { general view, but if we have difficulty in making decisions, we get the opinions } \\
\text { of local officials like headmen. Consultation is very important in this work. } \\
\text { 11.12.2019 }\end{array}$ \\
\hline $\mathrm{I}: 8$ & $\begin{array}{l}\text { We are an institution that strives to work according to supply. We try to do our } \\
\text { duty within the framework of laws. 19.12.2019 }\end{array}$ \\
\hline I:9 & $\begin{array}{l}\text { Everyone should do his duty, we think that we are doing our job successfully, I } \\
\text { do my job properly but this does not mean that we are sufficient and that we } \\
\text { can solve the problems radically. 13.01.2020 }\end{array}$ \\
\hline $\mathrm{I}: 11$ & $\begin{array}{l}\text { Our field of work is wide, the foundation has many functions, the social } \\
\text { assistance necessary to evaluate in the distinction between regular and irregular } \\
\text { assistance. It should be open to improvement, its effectiveness should be } \\
\text { evaluated.23.01.2020 }\end{array}$ \\
\hline $\mathrm{I}: 12$ & $\begin{array}{l}\text { There are questions that we have a fight against poverty. If poverty is not over, } \mathbf{I} \\
\text { do not consider myself successful. } \mathbf{0 4 . 0 2 . 2 0 2 0}\end{array}$ \\
\hline I:13 & $\begin{array}{l}\text { I comment on our staff successful in terms of quality and quantity but need to be } \\
\text { open to improvement. Our staff is highly educated, each of whom is a bachelor's } \\
\text { degree and does their job well. As an individual, I try to improve myself. I want } \\
\text { to add value to myself every day. } 04.02 .2020\end{array}$ \\
\hline I:14 & $\begin{array}{l}\text { There are no people in economically "zero" status like in metropolitan cities. } \\
\text { Our duty is to provide the first-degree living conditions of the person. Beyond } \\
\text { that, it is already outside the duties of the foundation. Our duties are basic in } \\
\text { this sense. 05.02.2020 }\end{array}$ \\
\hline I:16 & We endeavour to perform our duty within our means. 11.02 .2020 \\
\hline
\end{tabular}




\section{Macrothink

8 personnel interviewed from the foundation (50\%), who evaluated the work successful ; they frequently pointed out that they have an important place in fighting poverty ( 2 people), their activities in the district are sufficient ( 3 people), they cope with problems ( 1 person) and experience job satisfaction (2 people).

Personnel who emphasized that they need to be open to improvement frequently stated that they were trying for success ( 2 people), consulted for efficiency ( 4 people), and struggled with problems ( 2 people).

\subsubsection{Interpreting Difficulties About Working Lives}

Career improvement is the merger of the employee who makes career planning and the institution with career management in the work environment. Today, it is difficult to make medium and long-term career plans for internal and external reasons. At this point, career improvement plays a role in the safe approach of employees and new employees to work-life (Uğur, 2016: 177).

In the table below, the concerns of the personnel of social assistance and solidarity foundations regarding the career improvement within the sample were organized.

Table 7. Interpretation of Work-Life Challenges of Social Assistance and Solidarity Foundation Personnel

\begin{tabular}{|l|l|}
\hline $\begin{array}{l}\text { LEVEL 1) To be affected spiritually and financially by } \\
\text { events in working life, to bring work-related problems } \\
\text { home }\end{array}$ & $6 / 16, \% 37,5$ \\
\hline $\begin{array}{l}\text { LEVEL 2) Having security problems in the face of } \\
\text { dangerous events }\end{array}$ & $4 / 16, \% 25$ \\
\hline $\begin{array}{l}\text { LEVEL 3) To be blamed by the people who are addressed } \\
\text { when they cannot be helped }\end{array}$ & $11 / 16, \% 68,75$ \\
\hline $\begin{array}{l}\text { LEVEL 4) Being exposed to false representations of the } \\
\text { people they are }\end{array}$ & $7 / 16, \% 43,75$ \\
\hline LEVEL 5) Having career planning difficulties & $11 / 16, \% 68,75$ \\
\hline
\end{tabular}

Within the sample, $37.5 \%$ of the foundation's personnel mentioned that they brought the problems in their work-life home, this problem occurs in the form of empathy with the situation of the citizen who comes with the demand for help in general. $25 \%$ corresponds to encountering security problems. $68.75 \%$ comes to blame when there is no positive response to the demand for help. To encounter false statements is a problem of $43.75 \%$. It was expressed as a problem highlighted by $68.75 \%$ if career planning difficulties were experienced.

LEVEL 1) To be affected spiritually and financially by events in working life, to bring work-related problems home 
Table 8. Level 1 Comments of the Social Assistance and Solidarity Foundation Personnel

\begin{tabular}{|c|c|}
\hline $\mathrm{I}: 1$ & $\begin{array}{l}\text { It is a profession in which we have to communicate well with the citizen, we listen to } \\
\text { the problems of the citizens for hours. You have to understand it. Sometimes there } \\
\text { are even citizens who come here to explain their troubles and go without help. } \\
\text { This situation creates work-load for us. }\end{array}$ \\
\hline $\mathrm{I}: 5$ & $\begin{array}{l}\text { Our workload often reflects on the home. We cannot leave the events here, we } \\
\text { also think of the citizen who comes to us for help at home. }\end{array}$ \\
\hline I:6 & My impressions affect me when I go to review. \\
\hline $\mathrm{I}: 7$ & $\begin{array}{l}\text { I want to share a recent incident, a volunteer left a food voucher. A woman whom we } \\
\text { have been helping for years came to our institution to leave her child and consult us. } \\
\text { We persuaded her not to let go of her child and gave her a sum of money that we } \\
\text { collected with working friends as well as a food voucher until new help came out. I } \\
\text { hope we can change something. }\end{array}$ \\
\hline $\mathrm{I}: 8$ & $\begin{array}{l}\text { The opinions of the personnel who go to the investigation during the social assistance } \\
\text { process are effective, and the help decision is made according to the guidance of } \\
\text { those who go to the investigation. It is important to be objective, not to be affected } \\
\text { by work. }\end{array}$ \\
\hline $\mathrm{I}: 12$ & $\begin{array}{l}\text { Here he first gets a psychologically depressed mood, but he learns to remain } \\
\text { neutral with his work experience and focus on his job and solution over time. } \\
\text { Those who fail to do this cannot do this job anyway. }\end{array}$ \\
\hline
\end{tabular}

In Level 1 comments, foundation personnel stated that they brought this mood to their homes by being affected by the situation of the citizens who came with their demand for help and that they experienced a psychological breakdown. There are also those who state that they provided informal assistance, especially at the times they started work.

It was stated by many interviewees, who were interviewed that the spiritual effect was reduced in comparison with the age and professional experience when compared to the first time they started work.

It is clear that the profession requires strong empathy. In addition, it is very important not to show offending attitudes towards citizens who come for help. However, the most important emphasis will be that the personnel of the foundation receive training and psychological support so that they can be objective and not worn out in the face of events. In this way, they will be able to continue working efficiently in their jobs.

LEVEL 2) Having security problems in the face of dangerous events 


\section{Macrothink}

International Journal of Human Resource Studies

Table 9. Level 2 Comments of Social Assistance and Solidarity Foundation Personnel

\begin{tabular}{|l|l|}
\hline I:5 & $\begin{array}{l}\text { One of our problems, in terms of male outreach and investigators, is that; During the } \\
\text { household visits, if there is no man in the house, women living in the house for } \\
\text { privacy may not take the male officer inside. We have encountered the situation of } \\
\text { returning through the door. When we look at it from this point of view, the household } \\
\text { visit is a bit more troubled for male officials. Once, we had to involve the security } \\
\text { forces in the process of distributing public relief, because there was a stampede. }\end{array}$ \\
\hline I:12 & $\begin{array}{l}\text { Addict young people such as alcohol or other substance addicts who are touch a } \\
\text { sore spot of our institution. They get a small amount of social assistance from } \\
\text { here, perhaps, from the substance need they use, but we have to give it because } \\
\text { if we do not, they are involved in events with loss of life here, they are aggressive, } \\
\text { they disturb the shopkeepers. }\end{array}$ \\
\hline I:14 & $\begin{array}{l}\text { Since we are faced with the reactions of citizens who do not receive social assistance, } \\
\text { we can sometimes experience security problems. }\end{array}$ \\
\hline I:15 & $\begin{array}{l}\text { Everyone is doing everything here. When we go to social investigations, we have a } \\
\text { hard time. It would be better if there is a male staff. During the investigations, we } \\
\text { request one of our district governor's guards and they accompany us. }\end{array}$ \\
\hline
\end{tabular}

Level 2 comments emphasized privacy and security issues during the confluence or household visit due to citizens demanding assistance.

During the household visit, it may be inconvenient for only male or female officials to go, within the regards of the situation of the residents and privacy rules. Therefore, it is necessary to balance the hiring of male and female personnel within each foundation.

Regarding the confluence experienced during the public relief distribution, it was seen that there is a need for innovations on coordination and distribution.

The most important issue requiring security is within the framework of the substance addicts' demands from the personnel. Some interviewees stated that the life of the addicts has changed thanks to the foundation, while others perceive it as the riskiest situations. Here, the situation of the addict who comes with the demand for help and the attitude towards recovery should be taken into consideration and accordingly, it should be worked in coordination with the health institutions.

LEVEL 3) To be blamed by the people who are addressed when they cannot supply assistance 
Table 10. Level 3 Comments of the Social Assistance and Solidarity Foundation Personnel

\begin{tabular}{|c|c|}
\hline $\mathrm{I}: 2$ & $\begin{array}{l}\text { We have to work without discrimination. When we like our job, there is no difficulty, } \\
\text { but sometimes citizens can misunderstand us. We are a foundation that tries to } \\
\text { respond to demands. }\end{array}$ \\
\hline $\mathrm{I}: 3$ & $\begin{array}{l}\text { Working on a sensitive subject is the hard part of our mission. We can be in a } \\
\text { difficult situation when there is no assistance to the citizen. }\end{array}$ \\
\hline I:4 & $\begin{array}{l}\text { The statements are taken as a basis, but everything that is hidden during the } \\
\text { granting of aid is trying to be reconstructed. Besides the known, the unknown is } \\
\text { also investigated. }\end{array}$ \\
\hline I:6 & $\begin{array}{l}\text { We appeal to the elderly, but there are also substance addicts in our target audience, } \\
\text { we can encounter their reactions. }\end{array}$ \\
\hline $\mathrm{I}: 7$ & $\begin{array}{l}\text { We are on the razor's edge, if we do not do our job fairly, we will have to bear } \\
\text { the results. }\end{array}$ \\
\hline $\mathrm{I}: 8$ & $\begin{array}{l}\text { Because we are interested in individuals in the lowest income group, what we } \\
\text { encounter can often be unconscious and ignorant. The citizen facing us, "We cannot } \\
\text { provide assistance." when we say, they have to understand that we are law } \\
\text { enforcement, not lawmakers. We are frequently criticized on this issue. }\end{array}$ \\
\hline I:9 & $\begin{array}{l}\text { We have an obligation to take action for every citizen who comes here, as per the } \\
\text { right to petition, but the investigator who plays an active role in the issue of the } \\
\text { assistance determines his conclusion. Nevertheless, the reactions of the citizens } \\
\text { come directly to us. }\end{array}$ \\
\hline $\mathrm{I}: 12$ & $\begin{array}{l}\text { Often, the people we deal with can also direct their aggression to us when the } \\
\text { assistance they want is not available. This is one of the difficult positions of the } \\
\text { institution. }\end{array}$ \\
\hline $\mathrm{I}: 13$ & Citizens reproach us when no assistance comes out. \\
\hline $\mathrm{I}: 14$ & $\begin{array}{l}\text { As long as you work here, you can see all kinds of people. The richest person in the } \\
\text { village comes to us and the citizen who is not in poor condition can come to us. We } \\
\text { are reacted, the day is coming. }\end{array}$ \\
\hline $\mathrm{I}: 16$ & $\begin{array}{l}\text { Because we deal with people, they blame us when there is no assistance. In fact, } \\
\text { the conditions are determined in the law and the decision is made by the board of } \\
\text { trustees. Nevertheless, we come face to face with the citizen and we are exposed to } \\
\text { their negative behaviour. In this sense, we are experiencing troubles. There are } \\
\text { also communication difficulties, of course. }\end{array}$ \\
\hline
\end{tabular}

In Level 3 comments, citizen who demand assistance in the event that no assistance occurs, says to the personnel of the foundation, "You did not provide assistance."

As in the most clearly stated comment, foundations are not a decisive legislator for social benefits. Who can be helped has been determined within the framework of laws. Those who implement the assistance decision are the board of trustees. From this point of view, foundation employees are in a position to receive, analyse and transfer demands only. Exposure to blaming is another corrosive element in terms of their duties. However, this problem is one of the most difficult parts to deal with, as they are the direct contact with the 
citizens who come with a demand for assistance.

LEVEL 4) Being exposed to false statements of the people they are

Table 11. Level 4 Comments of the Social Assistance and Solidarity Foundation Personnel

\begin{tabular}{|l|l|}
\hline I:3 & $\begin{array}{l}\text { In the work we do, the most important thing is that the key point is creating } \\
\text { household visits, and it is essential that there is an accuracy share in these visits. }\end{array}$ \\
\hline I:4 & $\begin{array}{l}\text { The biggest problem of the foundation is not because of the working conditions and } \\
\text { opportunities, but because of the people who stated that they are in need of } \\
\text { assistance and insistently need help. }\end{array}$ \\
\hline I:6 & $\begin{array}{l}\text { No misrepresentation should be made at this institution. The time and other } \\
\text { citizens' rights should not be wasted. }\end{array}$ \\
\hline I:7 & $\begin{array}{l}\text { As a district foundation, we work in an area with low economic levels for some of our } \\
\text { citizens. There are many deficiencies such as shelter and infrastructure and they } \\
\text { apply to us for all kinds of problems. They are trying to solve all kinds of problems } \\
\text { here. This returns to us as work-load. Sometimes, they misinform their needs. }\end{array}$ \\
\hline I:8 & $\begin{array}{l}\text { Our field of study is a difficult area, sometimes we are exposed to being deceived } \\
\text { by false statements. }\end{array}$ \\
\hline I:9 & $\begin{array}{l}\text { The laws that are our priority in our work, however, we also take into account the } \\
\text { person's downtrod and credibility. In my early years I would have thought that all the } \\
\text { people who came here were informed us correct, I realized that it was not so with } \\
\text { time, now I am making more objective evaluations in my work. I also consider } \\
\text { the potential of people to lie. }\end{array}$ \\
\hline $\begin{array}{l}\text { I was an investigator staff from 2005 to 2013. There have been a lot of encounters } \\
\text { with unnecessary applicants. Therefore, we have difficulties in reaching real need } \\
\text { citizens. }\end{array}$ \\
\hline I:13
\end{tabular}

There are emphasis on the fact that the citizens who demand assistance at Level 4 disrupt the work of the foundation personnel due to their false statements, and therefore the workloads to rises.

Citizens can make their statements by distorting them to get help. In this regard, the integrated data control system supports foundation personnel. All information of citizens other than bank accounts is accessed by citizens' permission and pre-examination checks are provided.

Time and budget should be allocated to the truly downtrod citizens, by preventing citizens from making new demands to the institution, who persistently lie despite the checks or change the declaration information during the investigation. Thus, it is possible to provide the efficiency. However, in the current circumstances, this situation both increases the workload and divides the fund's financially support.

LEVEL 5) Having career planning difficulties 
Table 12. Level 5 Comments of the Social Assistance and Solidarity Foundation Personnel

\begin{tabular}{|c|c|}
\hline $\mathrm{I}: 1$ & $\begin{array}{l}\text { We are in contact with other foundation employees, but we cannot come together and } \\
\text { act for improvement. This is usually due to workload. }\end{array}$ \\
\hline I:5 & $\begin{array}{l}\text { When I first started work, as two people in the foundation, we worked under great } \\
\text { difficulties. Our job has become a little easier today, but this profession does not } \\
\text { allow people to improve themselves. }\end{array}$ \\
\hline I:6 & I also wanted to study a master's degree but I did not have the opportunity. \\
\hline I:7 & $\begin{array}{l}\text { I continue my master's degree, it is at the thesis stage, but it does not seem to end } \\
\text { with this trend. Our work is very intense, I hope it ends anyway. }\end{array}$ \\
\hline I:9 & I believe that there should be a psychologist working in the institutions. \\
\hline I:10 & $\begin{array}{l}\text { While dealing with the psychological situation of the citizens, I think that our office } \\
\text { staff disrupts the main duties and foundations need sociologists and psychologists. }\end{array}$ \\
\hline I:11 & If our staff could work fully, we could work more effectively. \\
\hline I:12 & $\begin{array}{l}\text { Our defectives are the workload of the staff. It can also be added to the } \\
\text { workload of the staff, to listen to the problems of the citizens with whom } \\
\text { dialogue is concerned and to be affected psychologically. }\end{array}$ \\
\hline I:13 & $\begin{array}{l}\text { During the investigation, we learned how to analyse from the outside and the state of } \\
\text { the citizen without entering the house. This is done by mastering in the work. } \\
\text { However, I think that education should be given. }\end{array}$ \\
\hline $\mathrm{I}: 14$ & $\begin{array}{l}\text { There are rarely problems with the investigations, but other than that, we come up } \\
\text { with the workload. }\end{array}$ \\
\hline $\mathrm{I}: 15$ & I want to give importance to my education, but the workload prevents this. \\
\hline
\end{tabular}

At Level 5, the emphasis was placed on the inability of investing in foundation personnel's own career planning due to workload.

Workload is an important factor. Personnel who want to devote time to their career planning delay this. Some foundations work with the lack of staff in the norm staff, which again has a workload increasing effect.

Here, it was emphasized that the necessity to provide on-the-job-training. Apart from this, the needs of specialists for foundations, who have received psychology or sociology education, are emphasized. 


\subsubsection{Benevolence Interpretations and Researcher's Observations}

Table 13. Interpretation Rates of Social Assistance and Solidarity Foundations' Personnel's Benevolence Attitudes

\begin{tabular}{|l|l|}
\hline $\begin{array}{l}\text { LEVEL 1) Despite the lack of personnel, we try } \\
\text { to come up with our job, we like our job }\end{array}$ & $10 / 16, \% 62,5$ \\
\hline $\begin{array}{l}\text { LEVEL 2) We share and consult with other } \\
\text { foundations on competence }\end{array}$ & $9 / 16, \% 56,25$ \\
\hline $\begin{array}{l}\text { LEVEL 3) Positive dialogues with people who } \\
\text { come to demand assistance (Observation) }\end{array}$ & $14 / 16, \% 87,5$ \\
\hline $\begin{array}{l}\text { LEVEL 4) Satisfaction expressed by people who } \\
\text { come to get assistance }\end{array}$ & $14 / 16, \% 87,5$ \\
\hline $\begin{array}{l}\text { LEVEL 5) Supporting attitude and information } \\
\text { sharing towards the researcher (Observation) }\end{array}$ & $13 / 16, \% 81,25$ \\
\hline
\end{tabular}

Despite $62.5 \%$ intense work pace, it was observed that they overcame their duties, $56.25 \%$ shared information with other foundations and well communicated, and that $87.5 \%$ stated the satisfaction status of the random citizens who came within the day of the interview. Observationally, positive dialogues with citizens coming with a demand for assistance are $87.5 \%$ and supportive attitudes towards the researcher are $81.25 \%$.

LEVEL 1) Despite the lack of personnel, we try to come up with our duties, we like our job

Table 14. Level 1 Comments on Social Assistance and Solidarity Foundation Personnel

\begin{tabular}{|c|c|}
\hline $\mathrm{I}: 3$ & $\begin{array}{l}\text { "I was not informed." There is no citizen who comes to us with his discourse. We } \\
\text { care about our business. }\end{array}$ \\
\hline $\mathrm{I}: 4$ & $\begin{array}{l}\text { Foundation staff is not sufficient, it is not possible to employ more staff at the } \\
\text { moment, especially due to the physical working conditions of the foundation, but we } \\
\text { can still handle our current duties with the workfellow. }\end{array}$ \\
\hline $\mathrm{I}: 5$ & $\begin{array}{l}\text { Unfortunately, the citizens coming here cannot express their needs very well. We try } \\
\text { to treat them as someone they trust, rather than personnel of the institution, so that } \\
\text { they can speak and relax and express their concerns better. You have to like this job. }\end{array}$ \\
\hline $\mathrm{I}: 6$ & $\begin{array}{l}\text { Three staff work in our institution, not enough, but thankfully we try to come up } \\
\text { with our duty. }\end{array}$ \\
\hline I:7 & We will have new staff demand in a short time. We need staff who like their job. \\
\hline $\mathrm{I}: 8$ & $\begin{array}{l}\text { In this district, our jobs are intense compared to the population, we are trying to } \\
\text { overcome by working devotedly. }\end{array}$ \\
\hline I:9 & $\begin{array}{l}\text { Although the financial situation is good people who apply to the institution are } \\
\text { disrupting our job and partially preventing us from reaching other citizens. However, } \\
\text { we strive to be sufficient. }\end{array}$ \\
\hline $\mathrm{I}: 12$ & $\begin{array}{l}\text { You understand people over time, and the citizen who exploits the situation can come } \\
\text { once again. The important thing is to make good observations and to be able to } \\
\text { adapt to the job. }\end{array}$ \\
\hline
\end{tabular}




\begin{tabular}{|l|l|}
\hline I:13 & $\begin{array}{l}\text { Our staff profile is each of those who are experienced over 8-10 years. We do the } \\
\text { work-division primarily through defined tasks. But there is no such thing as I cannot } \\
\text { do that work, everyone is already in help with each other. The most sensitive point for } \\
\text { the staff is household visits. We are trying to do all these by helping. }\end{array}$ \\
\hline I:14 & $\begin{array}{l}\text { Here, of course, the tasks are certain, but we all go to the investigation, with priority } \\
\text { in our own business. There are rarely problems with the investigation, but other than } \\
\text { that, we come up with the workload. }\end{array}$ \\
\hline
\end{tabular}

At Level 1, the emphasis is placed on the importance given to the job and the time spent on the job. Foundations' personnel expressed their time on work intensity by making concessions from their private lives spiritually.

Foundation personnel also stated sentences expressing the spiritual connection they had with their work. As well as achieving success in many works done by experiencing job satisfaction, the high impact of job satisfaction on productivity was emphasized in foundation studies. In addition, cooperation in the business environment rather than the division of labour is among the important highlights.

LEVEL 2) We share and consult with other foundations on competence

Table 15. Level 2 Comments on Social Assistance and Solidarity Foundation Personnel

\begin{tabular}{|c|c|}
\hline $\mathrm{I}: 2$ & We are in good communication with other foundations. \\
\hline I:5 & $\begin{array}{l}\text { If we face a situation that has not been requested before, we definitely consult with } \\
\text { other foundations to see if they have answered before. Because many tasks can come } \\
\text { to us outside of our own responsibility. If the solution is not in our institution, we } \\
\text { are at least guiding. }\end{array}$ \\
\hline $\mathrm{I}: 7$ & $\begin{array}{l}\text { I also know our colleagues from other foundations and we are in consensus with } \\
\text { many of them. }\end{array}$ \\
\hline $\mathrm{I}: 8$ & We have to well communicate with many of the colleagues at other foundations. \\
\hline $\mathrm{I}: 11$ & $\begin{array}{l}\text { Some of our colleagues may not be able to constantly work with various tasks, we are } \\
\text { not full staff. So, we have to do information exchange with other foundations. }\end{array}$ \\
\hline $\mathrm{I}: 12$ & $\begin{array}{l}\text { We work harmoniously within the institution, besides, I know my colleagues from } \\
\text { other foundations, we have consultations. }\end{array}$ \\
\hline I:13 & $\begin{array}{l}\text { We also have to cooperate with other foundations, if this is not the case, it will } \\
\text { not work. }\end{array}$ \\
\hline $\mathrm{I}: 14$ & $\begin{array}{l}\text { As with ourselves, we should consult with other foundations, this makes our job } \\
\text { easier. }\end{array}$ \\
\hline I:16 & We receive support from other foundations in guiding the applicant citizen. \\
\hline
\end{tabular}




\section{Ml Macrothink}

International Journal of Human Resource Studies ISSN 2162-3058 2020, Vol. 10, No. 2

The positive processes in terms of communication with other foundations are included in Level 2.

Even though the foundation personnel is experienced, they may encounter any demand they have not seen before, at this point consultation with other foundations is important. This is one of the signs of being in a sharing character. The consulted foundation also follows a guiding process. Mutual communication is very important, but this is more important in order to find solutions to incoming demands quickly.

On the day of the interview, at the rate of $87.5 \%$ at Level 3, positive observations were obtained as a result of observations, as a result of the dialogues with the citizens who came with a demand for help. While observing here, it was not paid attention to the foundation personnel only to perform their duties. In addition, it was paid attention by the researcher that they listen patiently to the problems, provide useful information and provide guidance, while doing so they display courtesy and naive attitude.

LEVEL 4) Satisfaction expressed by people who come to get assistance

Table 16. Level 4 Comments on Social Assistance and Solidarity Foundation Personnel

\begin{tabular}{|c|c|}
\hline A: & $\begin{array}{l}\text { We are very good with the employees of the institution, they listen to the people. At } \\
\text { least they are smiling are enough for me. They've known me since I came here, I'm } \\
\text { timid, I can't tell everybody like that. }\end{array}$ \\
\hline B: & $\begin{array}{l}\text { They care with people. I am a downtrod, what do I do if I do not get help from } \\
\text { here. }\end{array}$ \\
\hline C: & May Allah be pleased with them. \\
\hline D: & They are good. They were listening to me. \\
\hline E: & $\begin{array}{l}\text { I met foundation personnel thanks to my down syndrome brother during a household } \\
\text { visit to our neighbours. Meanwhile, my brother was looking through the window } \\
\text { and attracted the attention of the foundation officers. That day became a milestone for } \\
\text { our family and we were supported by the foundation. They have provided all my } \\
\text { needs. }\end{array}$ \\
\hline F: & $\begin{array}{l}\text { Our communication with the authorities of the institution is fine, I did not have } \\
\text { any problems. }\end{array}$ \\
\hline G: & Authority officials are interested, I am glad, if not, I would not come anyway. \\
\hline H: & They care me, fortunately, they are here. \\
\hline I: & $\begin{array}{l}\text { Someone gave me information about this institution. I am satisfied with the } \\
\text { institution officials. }\end{array}$ \\
\hline $\mathrm{J}:$ & $\begin{array}{l}\text { I contacted the institution myself. I am embarrassed when I ask for help, but of } \\
\text { course, I want it. Helpers to me. }\end{array}$ \\
\hline $\mathrm{K}:$ & I thank them. \\
\hline
\end{tabular}




\begin{tabular}{|l|l|}
\hline & My relations with the personnel of the institution are good. \\
\hline L: & They do a fair review, their job is difficult. \\
\hline M: & All they are very regard. \\
\hline N: & \\
\hline
\end{tabular}

At Level 4, in her interviews with citizens, the words emphasizing their satisfaction from the foundation employees were coded.

There is a rate of $87.5 \%$ here. In the interviews with the citizens in 14 of the 16 foundations visited, satisfaction was expressed against the personnel of the foundation. In only one foundation, the citizen expressed dissatisfaction exceptionally, in another foundation the foundation official did not find it appropriate to interview the citizen.

It is among the observations that communication between citizens and foundation workers is good despite the disruptions such as workload.

At level 5, it concerns the attitude of foundation officials about sharing information with the researcher. This rate is as high as $81.25 \%$. In 13 of the 16 foundations visited for the research, the foundation officials exhibited helpful attitudes towards the researcher. Besides, they also acted politely. In fact, the process that guided this research occurred after the dialogues with foundation employees.

\section{Conclusion and Evaluation}

Social assistance is becoming an increasingly important issue within the framework of social policy science. Social assistance, which is one of the most important issues of the social state, is a functional mechanism in the fight against poverty problem.

People with disabilities, elderly people, long-term unemployed, single-parent families who are deprived of social security or whose income is insufficient, most benefit from social assistance. Social assistance to be provided to these applicants is provided through processes such as income tests in many countries (Bahle et al., 2010: 448,449). Even though citizenship-based and unconditional social benefits are provided in Nordic countries where per capita income is high, the method followed worldwide is to provide social benefits by testing them with certain tools (Gough, 2001: 167).

In Turkey as in the world, there are some social assistance provider different official and voluntary agencies, local governments, non-governmental organizations. In this research, social assistance and solidarity foundations were discussed as an official social assistance institution. The study was carried out by considering the personnel of the institutions in the human resources discipline, rather than the aims and activities of these institutions in terms of social policy. Firstly, the profiles of the foundation personnel were analysed demographically, socioeconomically in terms of the sample.

One of the findings obtained is that foundation personnel is under the middle age limit. The 
age of employment for the personnel, which can be considered as young, also corresponds to the age of completing higher education. In terms of gender distribution, it is observed that women work predominantly in many of the foundations visited for interviews. It is among the suggestions that balanced distribution of male and female personnel will be beneficial for each foundation during the interview analysis. Because the work done is a human work. It is not a job with a vehicle and a machine, so citizens who are addressed in terms of communication can have their gender-based preferences in order to express their problems.

It is noteworthy that staff with a high level of education are widely employed in each institution visited for the interview. However, the need for personnel with different specialties such as psychologists was also mentioned. Among the reasons for this, besides relieving the citizens coming with the demand for assistance, being able to help those who apply to the foundations for all kinds of problems due to the name of the institution. Personnel of the institution are employed in contract status. The board of trustees is the decision maker in their dismissal as well as in their recruitment. However, the long length of time spent in the profession of the interviewed personnel attracts attention.

The view of the interviewees of the foundation personnel towards their own success is that they should be at half successful and at half open to improvement. While the personnel who found themselves successful were generally determining the criteria such as being able to come up with the district's problems that they are responsible for and finding the institution effective; the other the interviewers emphasized the necessity of being open to improvement and mentioned making efforts in their work and struggling for problems.

While interpreting the difficulties in working life, different issues have been touched, maybe due to the citizens who come with a demand for help or due to the intensity of work. There is also personnel who state that they bring these problems into their private life.

As a result, the benevolence attitude of the personnel of the institution was obtained through the method of semi-observational half-interview analysis. Foundation personnel mostly stated that despite the workload, they overcame the business by devotion and cope with the problems. There are many foundation personnel who state that they have strong communications with other foundations' colleagues. "How is your communication with the personnel of the foundation?" addressed to the citizens. With the answers received from the question, citizens stated that they are satisfied with the attitude, behaviour and discourse of the foundation personnel at high rates. During the research process, they acted high levels of supportive, sharing and guiding attitudes to the researcher. The personnel employed in the foundations undergo a necessary selection process, taking into account the workload and the nature of the job. Because foundation personnel should be helpful and sharing. In the research conducted, it was determined that these qualities are present in foundation personnel at a high rate. However, it was observed that they needed support due to workload.

\section{Acknowledgment}

"With gratitude for their efforts to my dear family..." 


\section{References}

Aktan, C. C., \& Vural, İ. Y. (2002). Poverty: Terminology, Basic Concepts and Measurement Methods, Poverty Alleviation Strategies. Ed.: C.C. Aktan. Hak-iş Confederation Publications. Ankara. (in Turkish).

ASAGEM General Directorate of Family and Social Research. (2010). Social Assistance Perception and Poverty Culture. Published by: S. Güneş. General Publication no: 144. Ermat Printing. Ankara. (In Turkish).

Bahle, T., Pfeifer, M., \& Wendt, C. (2010). Social Assistance. G. Castles, Stephan Leibfried, Jane Lewis, Herbert Obinger, and Christopher Pierson (Eds.). The Oxford Handbook of Welfare State. Oxford University Press. Oxford. 448-461. https://doi.org/10.1093/oxfordhb/9780199579396.003.0031

Buğra, A., \& Keyder, Ç. (Editors) (2006). Social Policy Articles. 2nd Edition. İletişim Publications. Istanbul. (in Turkish).

Demirbilek, S. (2005). Social Security Sociology. Legal Publishing. İzmir. (In Turkish).

Dodurka, B. Z. (2014). State Supported Outreach Center in Turkey - Study Report. Boğaziçi University Social Policy Forum. Istanbul. (in Turkish).

Doğan, S., \& Demiral, Ö. (2008). Employees' Journey towards Them in Human Resources Management: Talent Management. CU Journal of Social Sciences Institute, 3(17), 145-166. (in Turkish).

Esping, A. G. (1990). The Three Worlds of Welfare Capitalism. Cambridge. Polity Press.

Gough, I. (2001). Social Assistance Regimes: A Cluster Analysis. Journal of European Social Policy, 11, 165-170. https://doi.org/10.1177/095892870101100205

Güler, M. B. (2006). Women in the EU and Turkey: Equality in the Shadow of Inequality. Economic Journal, 469, 40-44. (In Turkish).

Gürbüz, S., \& Şahin, F. (2017). Research Methods in Social Sciences Philosophy- MethodAnalysis. 4th Edition. Seçkin Publications. Ankara. (in Turkish).

Kesgin, B. (2014). Social Assistance in Public Social Policies. Aç1lım Books. 2nd Edition. Istanbul. (in Turkish).

Kutlu, D. (2015). Formation of Social Assistance Regime in Turkey: Accumulation, Control, Discipline. NotaBene Publishing. Ankara. (in Turkish).

Merriam, S. B. (2013). A Guide to Qualitative Research Design and Implementation. Translation Editor: Selahattin Turan. Translation from 3rd Edition. Nobel Publishing. Ankara. (in Turkish).

Özmutaf, N. M. (2006). Human Resources and Stress in Organizations: An Empirical Approach. Ege University Journal of Fisheries, 1-2(23), 2006. (in Turkish). 


\section{Macrothink}

International Journal of Human Resource Studies

ISSN 2162-3058 2020, Vol. 10, No. 2

Sabuncuoğlu, Z. (2013). Human Resources Management (Practical). 7. Edition. Beta Edition. Istanbul. (in Turkish).

Saran, U. (1997). Social Assistance and Solidarity Promotion Fund and Social Assistance and Solidarity Foundations. Journal of Foundations, 26, 427-440. (in Turkish).

Selek, Ö. C., \& Peri, D. (2019). Women's Employment in Turkey and the European Union: A Comparison in the Context of Welfare Regime. Journal of Labour Relations, 2(10), 1-26. (in Turkish).

Şener, Ü. (2010). Social Security in Fighting Poverty. Outreach Mechanisms and Workforce Policies. Economic Policy Research Foundation of Turkey. TEPAV Policy Note. (in Turkish).

Taşçı, F. (2008). Turkey's Public Understanding of Social Assistance (1980-2007) an Analysis. Journal of Social Policy Conferences, 55, 127-149. (in Turkish).

Thurow, L. C. (1969). Poverty and Discrimination. Brookings Institution. Washington D.C.

Tokol, Aysen \& Alper Yusuf (Editors) (2018). Social Policy. 9th Edition. Dora Printing. Bursa. (in Turkish).

Uğur, A. (2016). Globalization and Human Resources Management - Lecture Notes. Sakarya Publishing. Sakarya. (in Turkish).

\section{Copyright Disclaimer}

Copyright for this article is retained by the author(s), with first publication rights granted to the journal.

This is an open-access article distributed under the terms and conditions of the Creative Commons Attribution license (http://creativecommons.org/licenses/by/4.0/). 